\title{
Creativity and Innovation in Cante from the Estado Novo to the present
}

\author{
Eduardo M. RAPOSO \\ CHAM, FCSH, Universidade NOVA de Lisboa \\ Email: Eduardomraposo0@gmail.com \\ ORCID: 0000-0001-6677-6619
}

\begin{abstract}
As we covered through Cante alentejano throughout the 20th century to the present day, we intend to identify its practices and roles in different historical periods, verifying its adaptability and capacity to recreate and innovate over time. We also intend to verify, in its relationship with the power, how Cante was able to review itself in these historical moments and how this contributed to its dissemination and also to be recognised as Intangible Heritage by UNESCO and what were the consequences of this recognition. In its ability to address new realities, we also want to measure how Cante combines in experimental projects with other musical expressions and how important the teaching of Cante is in the classroom for its protection.
\end{abstract}

Keywords: Cante, Alentejo, creativity, innovation

\section{Introduction}

Cante alentejano is traditionally associated with the sub-region of Baixo Alentejo, where the vast plains predominate and which is delimited to the north by Serra de Portel, the east by Spain, the west by the Atlantic Ocean and has as southern limit the mountains of the Algarve.

The north-lying sub-region, Alto Alentejo, administratively composed of Central Alentejo and North Alentejo, stretches north to the banks of the Tagus River. All of these form the Alentejo region. Nowadays we have verified the existence of Alentejo choral groups throughout the region, as well as in other parts of the country - Lisbon Metropolitan Area, and less expressively in the Algarve, Ribatejo or Porto - and in foreign cities such as Toronto, Luxembourg or Paris, mainly where there are vast communities of Portuguese people (and their descendants) who were born in Alentejo region.

It is the outcome of a dynamic process that has enabled the emergence of choral groups that accompanied the various migratory generations throughout the twentieth century. These groups, both in the Alentejo and in the diaspora, with innovation and creativity, sought to express their yearnings and the marks of their time, not forgetting the repertoire inscribed in the Traditional Songbook.

The process of innovation of Cante is still present in its origin region, Baixo Alentejo, with the proliferation of youth groups, after 2014, with the recognition of Cante alentejano as an Intangible Cultural Heritage of Humanity by UNESCO, as well as through the teaching of Cante in the school, a process of protection that started in 2007, but that spread mainly after 2014 .

There are also experimental projects, not only in
Alentejo, where the Cante appears associated with genres of popular and classical music, as well as other performing arts.

After contextualising diachronically, we delimited four periods of cante evolution: during the Estado Novo (1928-1974); after 1974; the foundation of MODA - Cante Alentejano's Association, in 2000; and after 2014.

We will try to understand how Cante proved to have the ability to innovate while walking the paths of diaspora, both in the past and today, as well as reflecting the revolutionary period, in particular, the Reforma Agrária [Agricola Reformation], and still today in the context of the diaspora.

We have been methodologically taking advantage of works published in different periods, from the eighties to 2018, by renowned academics on the subject, as well as documents prepared for the application to the World Heritage. We also carried out an inquiry directed to a restricted universe of master rehearses, trainers, musicians and singers paying attention to the meaning and the option for Cante, the Songbook and the emergence of new themes or the connection between the protection and the intersection of Cante with other musical expressions.

\section{Context and Characteristics}

Regarding the characteristics of Cante, we find the use of Ponto, Alto and Moda. Ponto is the solo voice that begins to sing, usually between "DO" and "MI". The Alto is the solo voice that follows the Ponto, in a sharper tone, usually a third above. Finally, the MODA is sung in chorus by the third voices, be it spontaneously in taverns or presented on stage or in contests.

"Majestosos corais alentejanos», ("Majestic Alentejo chorals"), a definition proposed the ' 50 s by the priest António Marvão (1903-1993) (considered 
one of the pioneers of the study of Cante), is what we now call the choral groups of Cante.

In the middle of the XX century, this polyphonic vocal expression of oral tradition sang by amateur choruses without any musical instruments was practically delimited to the Baixo Alentejo region. There was the successful creation of a choral group in Lisbon, in the 1950s, under the guidance of the Casa do Alentejo, a regional association based in the capital since 1923, (Vieira, 2005, pp. 158-159). Also, in Luanda, Angola, there is news of organised groups during the '60s (Lima, 2012, p. 73).

Though formal recognition only happened in the early twentieth century, the origins of Cante are quite ancient. The songs, called "modas", as mentioned by J. Ranita Nazaré, had their oral dissemination for centuries. Manuel Dias Nunes states that agricultural workers exclusively sang this repertoire. "Moda" was consequently the spiritual property of the entire rural population: men, women, and children knew and sang it, as they sometimes still do.

Nazaré refers that the poor and suffering people, spend their entire life 'moirejar' (working on the land), through mountains and valleys, regardless of weather conditions, finding in the choral songs a sweetness to balance the rudeness of the labour that subjugates them from the cradle to the grave (1987, pp. 30-31).

The theme of work, alongside those of nature and love, has always been present in Cante alentejano. The Cancioneiro de Serpa, collected by Maria Rita Ortigão Pinto Cortez between 1983 and 1987 (1994) includes at least nine modas, two of them that also constitute social criticism. On the other hand, the ethnomusicologist Salwa Castelo-Branco e Paulo Lima $(2018$, p. 20) refer to the lack of any songs of work or revolt, statement that a reading of the Cancioneiro (songbook) contradicts.

\section{Cante during the Estado Novo}

The Estado Novo inherited the military dictatorship established in 1926 and consolidated it, lasting until 1974. During this period Cante Alentejano was elected by the regime as one of the most representative practices of the Alentejo region, being the target of folklore and object of promotion by institutions such as the National Propaganda Secretariat (SPN) and the National Federation of Work and Joy (FNAT) (Moniz, 2015, p. 56).

This (attempt) to use Cante was not an act of kindness and promotion de per se. Rather the projection of Cante along with other practices may

1 During Christmas, there is an ancient Portuguese tradition of, from the 1st of January to the Epiphany (January 6th), small group of singers join to sing the janeiras [Januaries]. With musical instruments or not, they walk through the villages streets, stopping in front of the houses and sing traditional songs, mostly with religious have been due to an attempt to eliminate the wish of other popular expressive practices of social and/or political criticism challenging control by censorship, but also an action developed by the mediators in the service of the regime, who have contributed significantly to make Cante a regional stereotype (Moniz, 2015, p. 56).

This proves that Cante, during the Estado Novo, was not persecuted, but instead instrumentalised, because if, on the one hand, its practice as a formal presentation could be controlled - through previous (self) censored if necessary - on the other hand, their rural characteristics appealed to the ideological objective inculcated by the regime: the valorization of the rural heritage; of the traditional family, although to a lesser extent; and of Catholicism ${ }^{1}$.

The regulation of the rural heritage was used as a way of fighting against an urban culture, politically more active, that was opposed to the nationalist, ruralist, family, village vision, lacking wealth that characterised the Estado Novo (Moniz, Jorge, 2015, p. 56). It is proved that ethnography and folklore were used for ideological, political and propagandistic purposes.

Popular associations, such as FNAT, Casas do Povo, Centros de Alegria no Trabalho, were strongly restricted and controlled by the regime's organisations. Nevertheless, they played an essential role in increasing people awareness of the country's reality during the $1960 \mathrm{~s}$, until the fall of the dictatorship. If in the urban areas it was the Canção de Intervenção [Politically engaged songs] that had a leading role in the political awareness, in the rural areas, Cante will also play, in a way, this role.

In any case, by reinforcing and building an identity in Cante, the Estado Novo ends up contributing to the reinforcement of Cante as a cultural weapon (Moniz, 2015, p. 56)

Limited to the narrower and more enlightened circles of society generally without opinion intellectuals, students, political activists and trade unionists - the "canção de intervenção" existed and played a part in a repressed society: they pinched power. This happened not only due to explicit content reasons but also, and above all because they covered an anti-regime involvement and represented an appeal to values that Salazarism had wanted to take away from Portuguese society: intelligence, reason, solidarity (Raposo, 2007, p. 7).

\section{The case of Pias}

themes. Their payment by the house owners, called the janeiras, consisted traditionally of chestnuts, apples spicy sausages and black pudding. The groups have special insulting stanzas for those who ignore them and do not give the janeiras. In the end of the evening, the group divide what they have collected among themselves. 
Pias, in the municipality of Serpa, is a reference in opposition to Salazarism, considered as a "fortified" region against the dictatorship in Alentejo, where the opposition and especially the Communist Party (the only organised party) gained considerable popular support, a place where the Regime did not use Cante.

The Democratic Opposition in the Baixo Alentejo, Beja District, in 1969, began significantly in Pias, demonstrating its importance in opposition to the regime. According to scholar and the writer Urbano Tavares Rodrigues, candidate for the Democratic Opposition in Beja District, there was a radicalisation of the political attitude as the younger layers of the population felt victimised by the maintenance of the war (Mira, 2017, p. 41).

The village of Pias had, in 1968, two bands, two groups of amateur theatre and two popular Associations, which allowed to feed the social protest in "low voice" and give political support to the opposition to Estado Novo. However, it was in the taverns where people met regularly, talked, ate, drank and dreamed (Mira, 2017, p. 39).

According to Mira, in Pias, there were 12 taverns, partly because of the wine-making propensity of the land. They were the sacred place for all to speak. Taverns were designated by chapels, in slang, because they were places for the confession of sorrow for some, after a few glasses, and of hope, for others ${ }^{2}$. However, these taverns were regularly visited by GNR and PIDE informants spotted by members of the Portuguese Communist Party. Their presence required songs to be controlled song for not all themes could be sung at certain hours and days and with assumed risks. However, of the people from the land, there was no need to be afraid.

The themes, although more restraint when dealing with social conflicts, colonial war or the causes of the emigration, appear in modas (Mira, 2017, p. 40), like the following examples that became traditional:

a) About the need for emigration in search of better living conditions

$$
\begin{aligned}
& \text { Quando eu cheguei ao Barreiro } \\
& \text { No barco que atravessa o Tejo } \\
& \text { Chora por mim que eu choro por } \\
& \text { Já deixei o Alentejo. [... }]^{3} \text {. } \\
& \text { Algum dia em tendo sede } \\
& \text { la beber ao teu monte }
\end{aligned}
$$$$
\text { Chora por mim que eu choro por } \mathrm{ti}
$$

2 For a short example of singing cante in a tavern after 1974

https://www.youtube.com/watch?v=GBhgE3EMQy4 . There is also a documentary on cante available at https://www.youtube.com/watch?v=vovwT036xp4 3 "When I arrived at Barreiro/on the boat that crosses the
Agora estou mal contigo
Vou beber a outra fonte.
Meu Alentejo ditoso
Sou obrigado a deixar-te
com as lágrimas nos olhos $[\ldots]^{4}$

Though the tavern was the birthplace of cante with men standing by the counter making a moda, with the countertenor and the bass in the middle of the group (Mestre, 2014), Cante about work or love is also sang by male and female groups while working in the fields.

\section{After 25 April 1974}

With the socio-political changes brought by the democratic regime, Cante spreads a lot. In 1974 there were 20 Alentejo choral groups, but the number grew to 73 groups in 1998. It is an increase of 53 groups, showing the increase of traditional music groups throughout the country, especially in the first ten years after the revolution (Moniz, 2015, p. 56).

Of the total of Alentejo choral groups, $46,3 \%$ are based in predominantly urban areas, which points to a relocation of the Cante, regarding its origin (Moniz, 2015, p. 56). However, this growth was not confined to the Diaspora, although there was an effective growth in the industrial area of Lisbon and Setúbal, an outcome of the migratory process during the 1960s. The growth is also registered in Alentejo urban centres.

In a first moment, we find themes of social criticism or apologetics, in the context of the Reforma Agrária (Agriculture Reform) and the revolutionary period, giving Cante a musical and literary expression of political intervention, with texts with explicitly content sung introduced in the repertoire of melodies that integrate the canon of Cante.

Topics such as Baleizão by the Grupo Coral do Sindicato dos Operários de Aljustrel [Choral Group of the Workers' Union of Aljustrel]; "A Reforma Agrária é o que mais invejo" by Grupo Coral União Alentejana, Baixa da Banheira; or "Ó Cidade do Barreiro" by the Grupo Coral Alentejano Amigos do Barreiro. This last group was the first to set interesting examples of Modas with a political nature, where resistance, intervention, and the vindictive character are evident, shaping Cante's political engagement (Castelo-Branco and Lima, 2018 , p. 75 ) thus creatively adapting Cante to this historical moment.

In this period it will be the Local Power, that emerges with the establishment of democracy,

Tagus,/Cry for me as I cry for you,/I've left Alentejo." 4 "When I was thirsty/ I went to you farm./Now I can't live with you/I must drink in another fountain/My joyful Alentejo I must leave you,/with tears in my eyes." Soundtrack available here: https://www.youtube.com/watch?v=vovwT036xp4. 
which will be the leading supporter of Cante. The Town Councils assume the Cante as the identity paradigm of the Alentejo (Moniz, 2015, p. 57) and will have a decisive role in its support, be it financial, logistical or bureaucratic (Raposo, 2015, p. 20).

Casa do Alentejo, Association of people from Alentejo, based in Lisbon, in the former Alverca Palace, also contributed to the agglutination, in the 80 s, organising large gatherings and parades and making its rooms regularly available, enabling an expansion stage for the emergence of new groups. By then, there were already more than two dozen active groups in the Lisbon Metropolitan Area and Setubal (Teixeira, 2015, p. 59). The beautiful Arabic Courtyard of the Casa do Alentejo became a paradigmatic place, where the choral groups either from the diaspora or from the Alentejo always registered their presence and performances.

\section{The Cante Congress and the creation of Moda}

At the end of the '80s, political modas fell into disuse, while traditional ones, inscribed in the traditional Cancioneiro, are progressively recovered (Castelo-Branco and Lima, 2018, p. 76). In the 90s, we register an ageing of the Cante and a weaker ability for attracting younger people. This led to the organisation of the 1st - and only Congress of Cante, in Beja, in 1997.

An intense debate led to the conclusion of the need for renovation and revival of the Cante, competing for its ennoblement, valorisation, promotion and protection.

Two aspects stood out: the teaching of Cante and the creation of a federation of Alentejo folklore. The second led to the creation, in 2000, of MODA Cante Alentejano Association, congregating a large part of the 110 to 120 groups then active. MODA became a forum for debate and action to the renovation, ennoblement and protection of Cante. On the other hand, the project "Cante nas escolas" [Cante in the Schools] starts in Almodôvar primary schools, in 2007.

As Raposo stresses, the aim is to awaken the taste for the Cante, to value and to make known the culture and the traditions of the Alentejo and above all, to motivate the new generations for the preservation of traditional music. It is intended to form not only voices for Cante but also new audiences for what is the ex-libris of the region and a landmark as cultural heritage $(2015$, p. 68$)$ Although there have previously been occasional

5 As in the case of the Choral and Ethnographic Group Carapinhas de Castro Verde, or the Choral Children Group the Rouxinóis, from Beja.

6 The Viola Campaniça, literaly "viola from the countryside", is a 10 metal string viola used in Southern experiences, from which some more consistent or ephemeral projects have arisen ${ }^{5}, 2007$ marks the beginning of a structured work, of the teaching of Cante in the classroom, with the use of formal and informal methods, which were later followed in Castro Verde, Serpa, and Beja, and is currently widespread throughout the Lower Alentejo.

This process, begun by Pedro Mestre, a young but inevitable figure of Cante and Viola Campaniça ${ }^{6}$, is now practised by other musicians and trainers such as Paulo Ribeiro, David Pereira, Paulo Colaço and Paulo Bicho, the latter in Almada, where the systematic teaching in the classroom started in 2017.

Almada, in Lisbon metropolitan area, has currently eight classes and is the only sustained project of Cante's taught in the diaspora, though there are occasional experiences also in Moita, Damaia, Cascais and Palmela.

The teaching of Cante, involving adults and children outside the Alentejo community or even with origins in other latitudes or continents, enables Cante's protection, enables its innovation, widens and diversifies the audiences, as well as the recreation of Cante beyond of its original locations.

\section{The Patrimony of Cante}

In barely 14 years - from 1998 to 2012 - the creation of new groups in the Alentejo was exponential. When the Inventory-catalog of Groups of Cante Alentejano was analysed to produce the application proposal to the Representative List of the Intangible Cultural Patrimony presented to UNESCO, there were 140 groups, almost the double of those active 1998. Currently, as a consequence of the rise of Cante to Intangible Cultural Heritage, the existing groups around 150 to 160 , being not easy to count them, especially the ones with young people, which appear to start and be inactive or end very frequently. From the 16 youth groups that emerged after 2014, about half are active now. Groups and classes of Cante have also appeared in the scope of Senior Universities - the case of Almada - and other institutions for the elderly.

The UNESCO approval in 2014, has contributed to the recognition of Cante both nationally and internationally, stimulated the interest of young people in this expressive form, leading to the creation of choral groups exclusively by young people, and encouraged their integration into some existing groups, and the formation of small groups constituted by singers and accompanied by the viola campaniça (Castelo-Branco and Lima, 2018, p.
Alentejo, mainly in the left bank of river Guadiana. Its peculiar sound is determined by the way strings are arranged in five pairs of strings, by the way they are tunned and for being played mainly with the thumb. 
13). It also reinforced the realisation of experimental projects, where Cante crosses with other genres of popular and erudite music, as well as other performative arts (dance, theatre). Cante won the possibility to evolve creatively, without losing its main characteristics, by finding new and complementary means of expression.

Nowadays, listening to Almada most important group - the "Friends and Ethnographic Group of the Feijo Alentejo" - one finds an innovated repertoire that introduced themes as Cante as World Heritage, the experiences of the great community of 50,000 inhabitants with familiar ties in Alentejo, or the construction of the long-awaited Alqueva dam, with its promise of having a lake that would put an end to the endemic need of water in southern Alentejo.

On the other hand, we have identified musicians and groups that have crossed different genres and musical styles incorporating and reinventing Cante.

\section{Final Notes}

We verified that throughout the historical periods in analysis, Cante alentejano could innovate and to self-re-create thematically.

Although with the traditional Cancioneiro always present and in the background, it evolved in time giving expression to what the population felt, thought, their physical and political needs, their anxieties, and so forth. It also was and keeps being a means to express joy, love and above all the deep sense of belonging to a specific territory, to a specific culture, to a shared heritage.

Assuming itself as a significant brand of Alentejo's identity, Cante, instrumented by the Estado Novo, knew how to be a focus of resistance in the informality of the taverns in the dictatorship and apologetic cry of the conquest of the dignity of the humble rural workers with the end of the agricultural exploitation

Being nature, nostalgia, love and work structuring themes, however, the claiming and denouncing posture of the will of the powerful also marks Cante thematic, be it the profound social exploration during the dictatorship, or the post-revolution period, with situations of repression to the participants in Agrarian Reform.

The teaching of Cante, broadening and diversifying its public, is a substantial contribution for the safeguarding of Cante alentejano. Participation in experimental projects with other musical expressions and performing arts seems to play an essential role in the dissemination and evolution of Cante alentejano.

The appointment as World Heritage, made possible the recognition of Cante nationally and internationally, dignifying it, stimulated the interest of young people leading to the creation of youth choral groups. Another consequence is the internationalisation of the Cante, revitalising of choral groups in America and Europe, or emerging new ones such as the Rancho dos Cantadores de Paris, a mixed group of French, exemplifying the spread of Cante on a world scale.

\section{Acknowledgement:}

This chapter had the support of CHAM (NOVA $\mathrm{FCSH} / \mathrm{UAC}$ ), through the strategic project sponsored by FCT (UID/HIS/04666/2019)

\section{Bibliographical References}

Castelo-Branco, S. \& Lima, P. (2018). Cante Alentejano Patriomónio Cultural da Humanidade. Cantes (Vols. 1- 4). Lisboa: A Bela e o Monstro, Edições/Público Comunicação Social SA.

Cortez, Maria Rita Ortigão Pinto. (1994). Cancioneiro de Serpa. Serpa: Camara Municipal de Serpa.

Lima, P. (2012) Inventário-catálogo dos Grupos de Cante Alentejano. Documento de Trabalho para a Proposta de Candidatura do Cante Alentejano à Lista Representativa do Património Cultural da Humanidade, a Apresentar à UNESCO. 2012. Janeiro.

https://www.luardameianoite.pt/cante/cantealent ejano\%20inventariogrupos.pdf.

Mira, F. de. (éd). (2017). O Cante à Moda de Pias - Grupo Coral e Etnográfico os Camponeses de Pias. Coimbra: Terra Ocre edições.

Moniz, J. (2015). Cante e Diáspora. Do Estado Novo à Actualidade. Memória Alentejana, (35/36), 55-57.

Nazaré, F. de. (coord.). (1979). Música tradicional portuguesa - Cantares do Baixo Alentejo. Lisboa: Instituto de Cultura Portuguesa.

Raposo, E. M. (2015). Canto de Intervenção 1960-1974. (3a ed.) Lisboa: Público, Comunicação Social, SA.

- (2015). Pedro Mestre. Os mais jovens são a força motriz capaz de garantir o future do Cante. Memória Alentejana, (35/36), 66-70.

. (2015). Joaquim Afonso A salvaguarda do Cante passa pelo rigor, pela paixão, pelo trabalho de base com os jovens, está na alma dos cantadores. Memória Alentejana, (35/36), 18-21.

Raposo, Eduardo M. \& Neto, Ana Pereira. (In Press). “Cante Intangible Cultural Heritage of Humanity: representation of traditional art in the city of Almada." In AMPS Proceedings Series Tangible Intangible Heritage(s)Design, Social and Cultural Critiques on the Past, Present and the Future. The University of West of London, London, UK. 13-15 June (2018).

Teixeira, F. L. (2015). O Cante Alentejano, Património Vivo do Alentejo. Memória Alentejana, (35/36), 58-61.

Vieira, R. R. (205). O Associativismo Alentejano na Cidade de Lisboa no Séc. XX. Lisboa: Edições Colibri/Casa do Alentejo. 